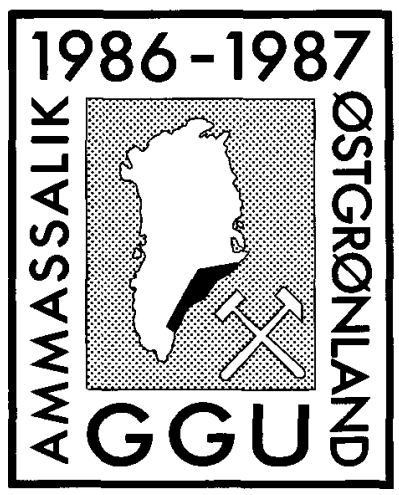

\title{
The Ivnartivaq complex, Sermilik, Ammassalik
}

\author{
C. K. Brooks and G. Stenstrop
}

\begin{abstract}
The Ivnartivaq complex is a small ultramafic body enclosed in quartzo-feldspathic gneisses. It consists largely of serpentinite but has a core of fresh dunite and abundant veins of asbestiform minerals containing amphibole, talc, chlorite and magnetite. The complex is early Proterozoic in age. It probably does not contain economic deposits of either industrial or metallic minerals.
\end{abstract}

\section{Introduction}

The Ivnartivaq complex is a Precambrian ultramafic body of relatively small extent which outcrops on the eastern side of Sermilik about $20 \mathrm{~km}$ north of the settlement of Tiniteqilâq near the hunting hut at Paornakajît and about $50 \mathrm{~km}$ in a direct line north of the town of Ammassalik (fig. 1). A brief mention of the ultramafic rocks of the Ammassalik area was made by Wager (1934).

A detailed investigation of this body was made in the summer of 1986 with the aim of producing a geological map and evaluating its economic potential for chromite, sulphides, platinum group metals and industrial minerals. In this report only the geological relations are described, assay results being not yet available.

\section{General geology}

The ultramafic rocks outcrop in a northward facing, bowl-shaped depression of relatively smooth topography which reflects the much lower degree of resistance to erosion of these rocks compared to the surrounding quartzo-feldspathic gneisses. The highest part of the complex is at an altitude of $545 \mathrm{~m}$ dipping to about 320 $\mathrm{m}$ to the north-northwest.

The complex measures approximately $300 \times 800 \mathrm{~m}$ and is surrounded by banded grey gneisses with amphibolite horizons and boudins. It is generally elongated in the direction $125^{\circ}$ with contacts dipping $85^{\circ}$ to the northeast. However, the northwestern part extends in a northerly direction. The overall shape of the body is concordant with the foliation of the gneisses and this direction is followed by trains of enclosed gneiss and by fabric in the ultramafics in the few instances where this can be discerned. The northwesterly extension appears to be grossly discordant with the gneiss foliation. Along the southern margin, the contact is seen to undulate on a metre scale, with sepentinite and partly serpentinized dunite interfingering with the gneiss. Lenses of serpentinite are locally embedded in the gneiss adjacent to the contact. The largest of these lenses was seen to be approximately $3 \times 4 \times 10 \mathrm{~m}$ in size, although they are generally much smaller, down to the size of a football, and are elongated in the direction of the gneiss foliation. These lenses are rimmed by zoned assemblages of fibrous secondary minerals (largely talc, magnesite, chlorite and tremolite) from a few centimetres to a few decimetres in thickness. Sometimes, the boundary of the ultramafics appears to cut the gneiss foliation, e.g. along the contacts of the northwestern extension, but nowhere could the relations in such places be examined in detail owing to cover by snow or talus.

\section{Lithology}

From the sketch map in fig. 2 it can be seen that the bulk of the body is composed of serpentinite, i.e. around $80 \%$ or $0.17 \mathrm{~km}^{2}$. Fresh dunite comprises most of the remainder; around $0.04 \mathrm{~km}^{2}$. Also present within the confines of the body are amphibolite and anorthosite sheets, a magnetite-rich body, gneisses (presumably as xenoliths), and an abundance of veins characterized by minerals of asbestiform habit.

Dunite is mainly found in two areas of positive relief, centrally placed within the serpentinites. It forms rounded outcrops which weather to a coarse olivine sand or gravel. In places, striking 'woolsack' weathering forms are developed due to preferential disintegration along a blocky joint system with a spacing of 1 to $3 \mathrm{~m}$ (fig. 3). The dunites are light green in colour with a medium to coarse grain size and an equigranular texture. Dunites are extremely difficult to sample due to the crumbly nature, but most of them appear to be 


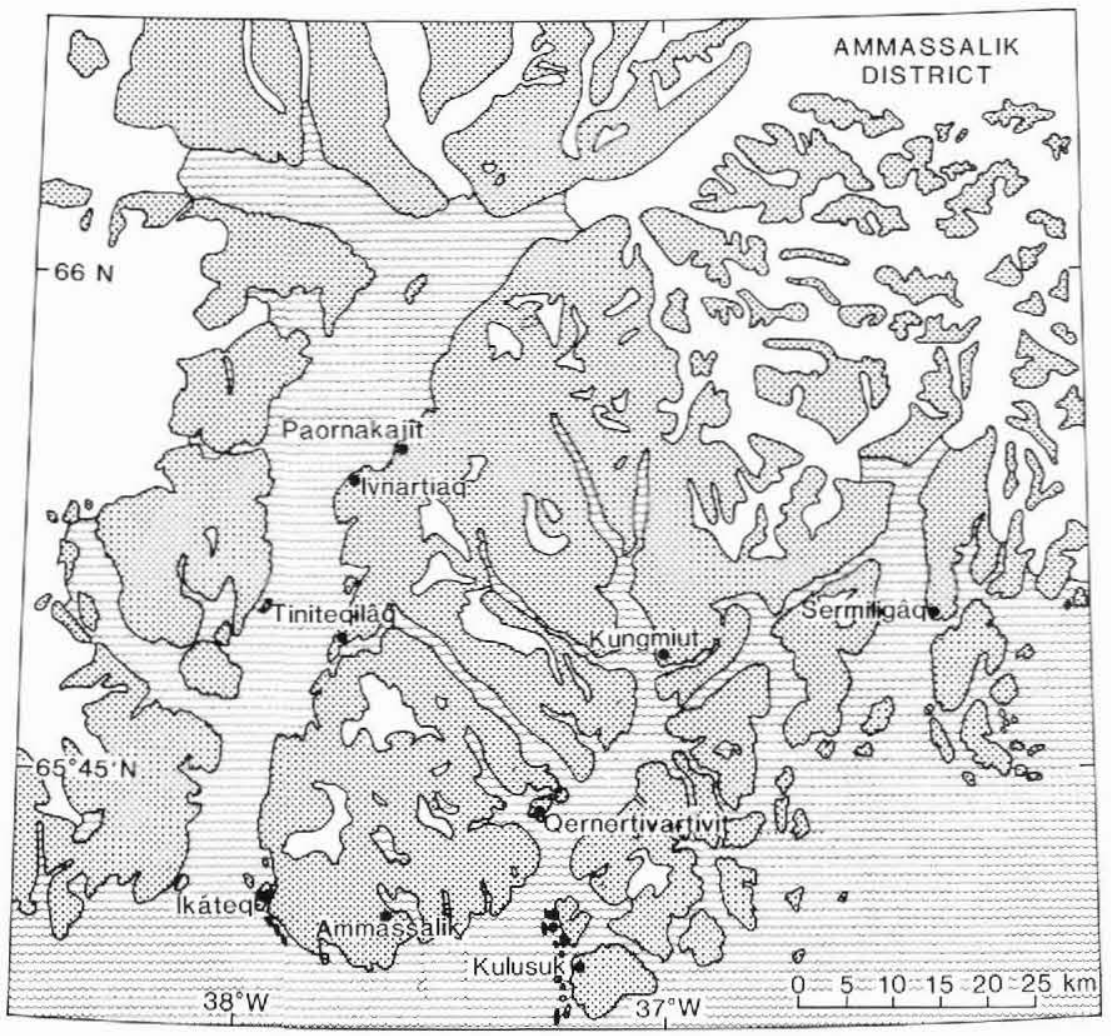

Fig. 1. The Ammassalik district showing the location of the Ivnartivaq complex.

OXIDE RICH AMPHIBOLITE

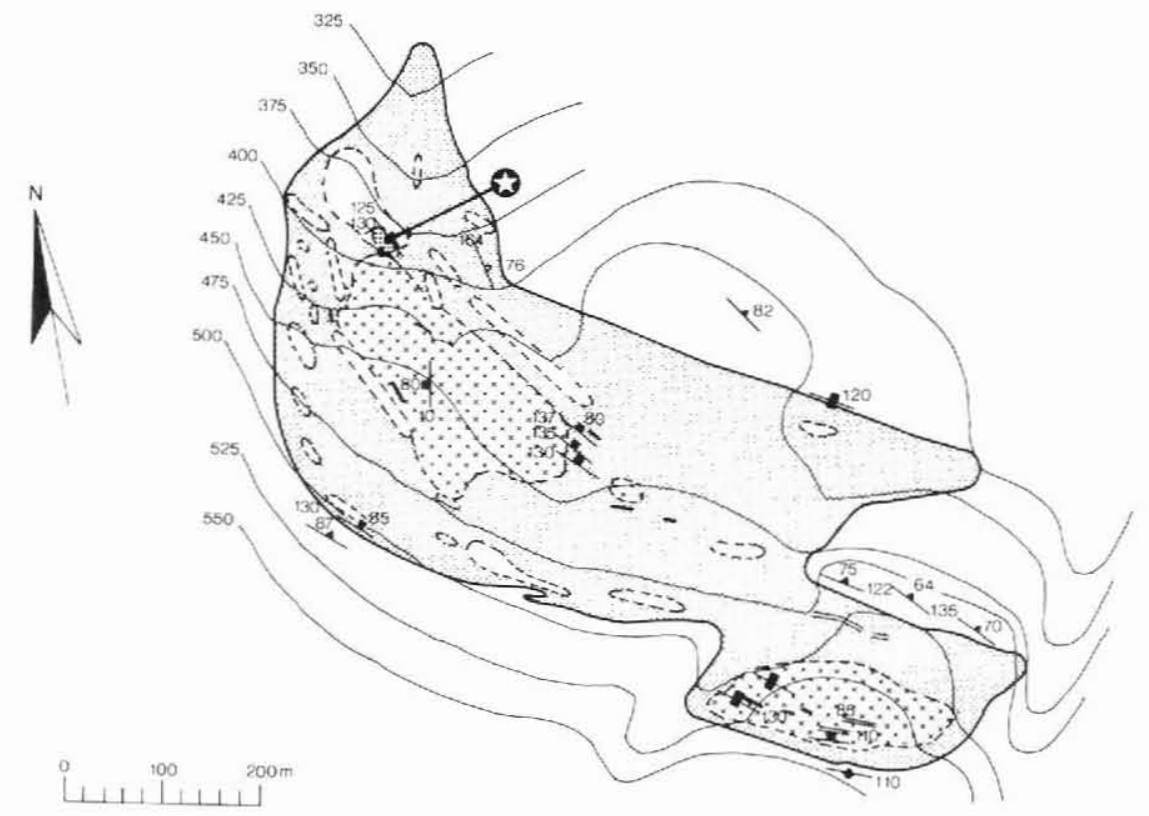

$[\because:::: ?:$ DUNITE
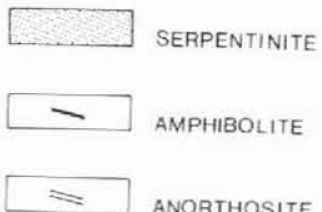
ANORTHOSITE
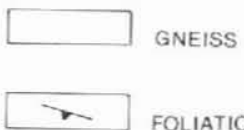

FOLIATION

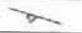
SHEETING

Fig. 2. Sketch map of the Ivnartivaq complex. Star shows location of detailed sketch of fig. 4 . Contours are in metres, based on spot heights by ancroid barometer. 


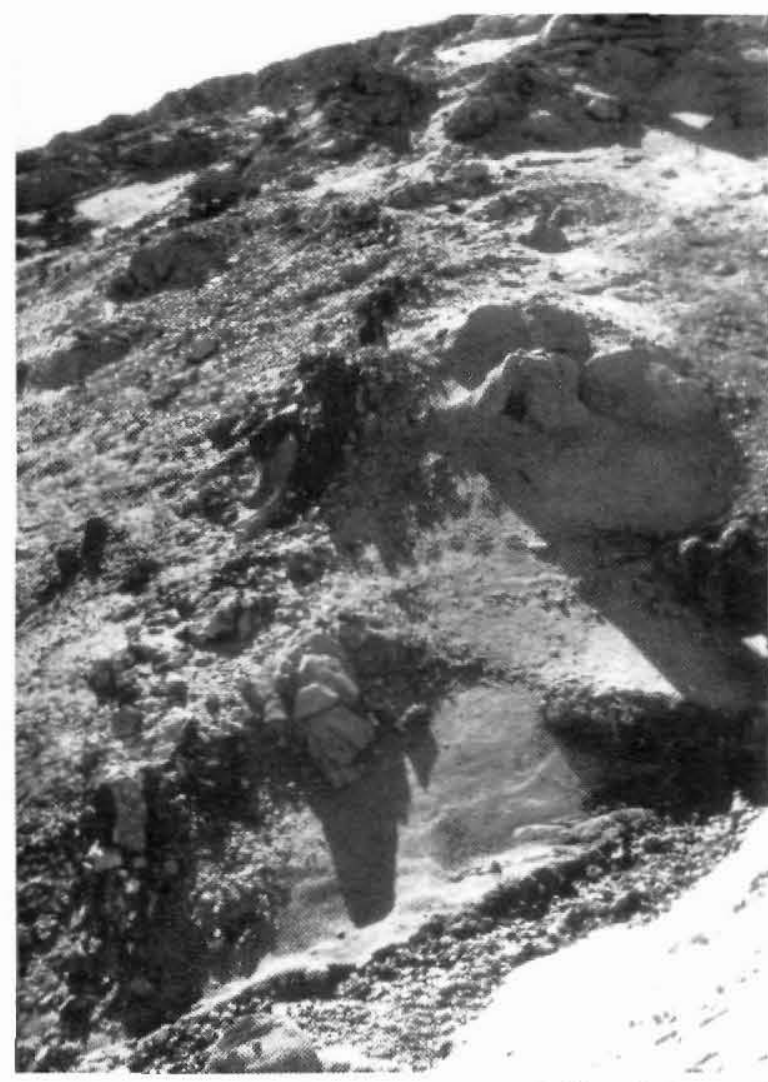

Fig. 3. Typical outcrops of dunite surrounded by olivine sand and gravel. The anorthositc-amphibolite sheet (running from centre to lower left) is about $1 \mathrm{~m}$ thick.

rocks composed almost exclusively of forsteritic olivine $(\mathrm{Mg} /(\mathrm{Mg}+\mathrm{Fe})$ around 0.95 - microprobe analysis $)$. Brown enstatite occurs as a minor constituent in restricted areas where it forms ill-defined, elongated clusters or schlieren oriented parallel to the foliation of the country rocks. This enstatite has $\mathrm{Mg} /(\mathrm{Mg}+\mathrm{Fe})$ similar to that of the olivine and about $2.5 \% \mathrm{Al}_{2} \mathrm{O}_{3}$. In addition, small amounts of spinel are present in these clusters. It has a composition of $\left(\mathrm{Mg}_{0.8} \mathrm{Fe}_{0.2}\right)\left(\mathrm{Al}_{1.8} \mathrm{Cr}_{0.1}\right) \mathrm{O}_{4}$ and is pleonaste i.e. a spinel-hercynite solid solution. More commonly enstatite is concentrated in decimetrethick veins, which may follow the jointing, where it forms a monomineralic rock. Enstatite may also become increasingly abundant in the dunites in the neighbourhood of the amphibolite sheets and here the rock becomes a harzburgite, although of only a few decimetres extent. The only other constituent of the dunites is magnetite $\left(\mathrm{Cr}_{2} \mathrm{O}_{3}=6.5 \%, \mathrm{MgO}=2.4 \%, \mathrm{TiO}_{2}\right.$ around $10 \%$ ) which occurs in accessory amounts.

Serpentinites form low, rounded outcrops which are commonly elongated parallel to the general trend of the
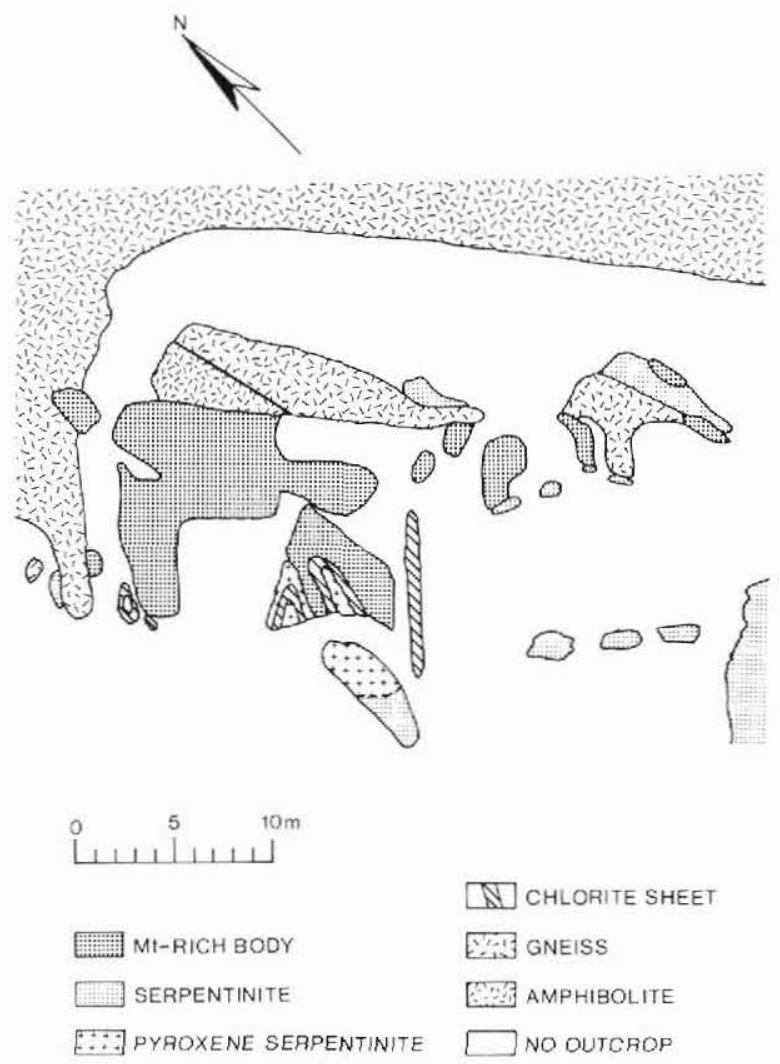

Fig. 4. Detailed sketch map of the area shown by the star in fig. 2. showing outcrop of magnetite-rich rock.

body. They have characteristic chocolate brown weathering colours which contrast strongly with the green dunites. Jointing is much closer spaced than in the dunites and locally a sheeting, almost a fissility, is developed with a spacing of $\frac{1}{2}$ to $2 \mathrm{~cm}$. This sheeting occurs close to the contact, to which it is parallel.

The contact between the dunites and the serpentinites is seen, even at a distance, by the marked colour change from pale green to chocolate brown. It is gradational over several metres, although most serpentinites examined in thin section contain at least some residual fresh olivine. As in the dunites, opaque oxide is a ubiquitous accessory phase.

Amphibolite sheets are steeply dipping and follow the overall trend of the ultramafic complex. These sheets show pinch-and-swell or en echelon structures. They range in thickness from $\frac{1}{2}$ to a few metres and commonly show a zonation with an outer zone, $2 \mathrm{~cm}$ to a few decimetres in thickness, of coarse-grained black hornblende and an inner zone which is medium to finegrained and banded, with variable amounts of plagioclase. These sheets contain pegmatitic lenses of plagioclase, often rimmed with coarse hornblende. Some of 


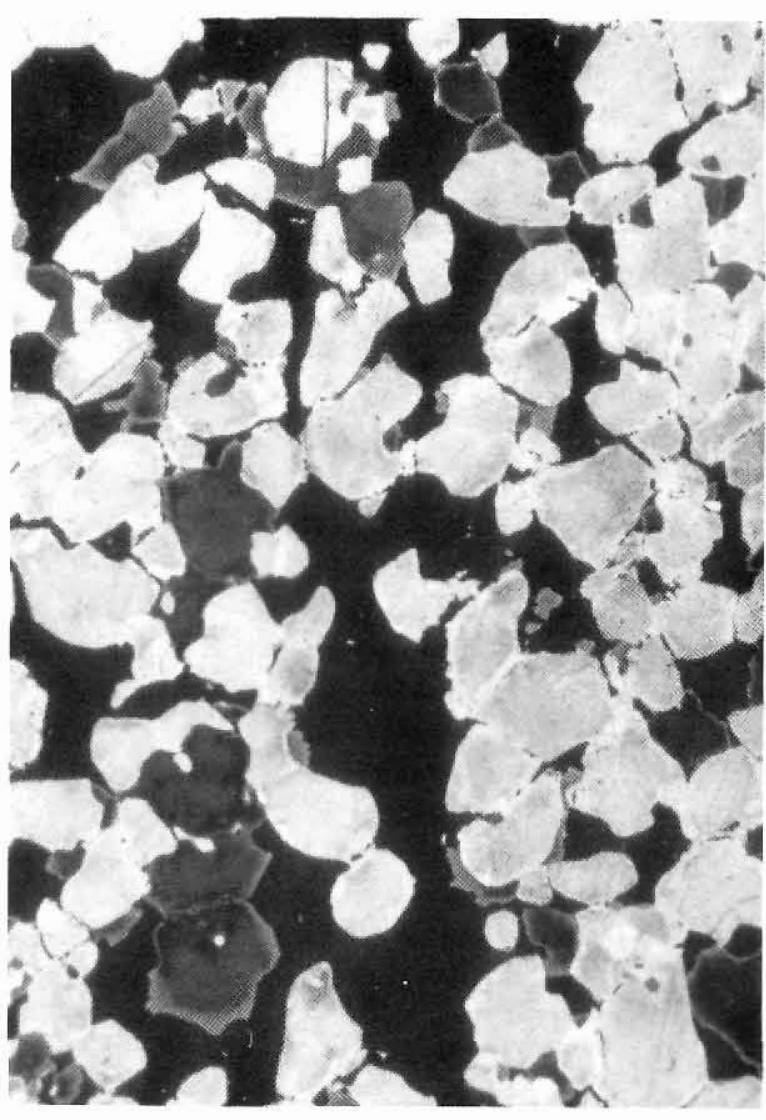

Fig. 5. Sample from magnetite-rich body shown in fig. 4 . It has an apparent heteradcumulus texture. Light grey: clinopyroxene; dark grey: spinel; black: magnetite.

the rocks called amphibolite in the field are in fact pyroxenites with well-developed cumulus textures although many amphibolites also show this type of texture and it cannot be concluded that the amphibolites have been formed by metamorphic reactions. Hematite with virtually $0 \% \mathrm{TiO}_{2}$ is important in some of these sheets and has interstitial relationships.

Anorthosite sheets differ only from the amphibolites, which are always dominated by hornblende, in that they contain mainly coarse plagioclase (with a grain size up to $5 \mathrm{~cm}$ ) and less than $10 \%$ hornblende. Also these anorthosites are rimmed by coarse-grained hornblende, although locally this zone may be absent. The anorthosite sheets also show pinch-and-swell structures with the plagioclase being much finer grained in the pinched zones.

An unusually large amphibolite body in the northern part of the complex and located adjacent to a major gneiss inclusion is denoted in fig. 2 by a star. This area is shown in more detail in fig. 4 . The body is a mediumgrained amphibolite, with minor plagioclase, similar to

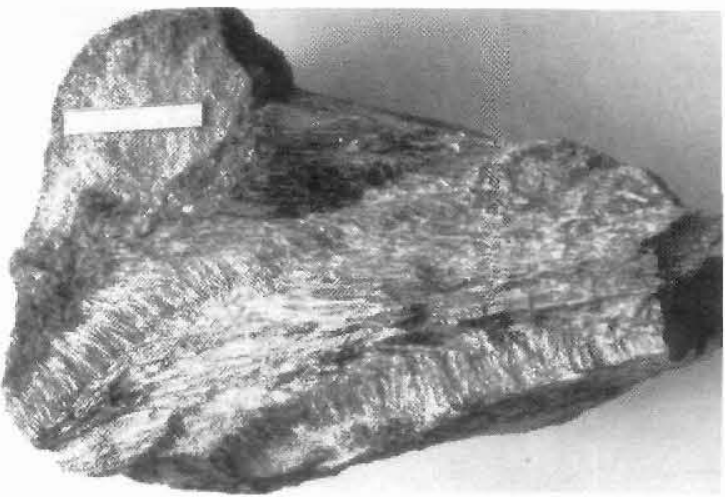

Fig. 6. Vein of asbestiform amphibole showing kinking of fibres. Note $4 \mathrm{~cm}$ scale located on country rock.

smaller bodies formed on strike and probably detached from it by deformation. This body contains a large oxide-rich area with a surface area estimated to be around $230 \mathrm{~m}^{2}$. It consists of cumulus clinopyroxene and spinel enclosed in a heteradcumulus mass of magnetite (fig. 5). The magnetite has only about $2 \% \mathrm{Cr}_{2} \mathrm{O}_{3}$ and the spinel (which is green in thin section) is a plenonaste with $\mathrm{Mg} /(\mathrm{Mg}+\mathrm{Fe})=0.75$. The clinopyroxene has over $7 \% \mathrm{Al}_{2} \mathrm{O}_{3}$ and $\mathrm{Mg} /(\mathrm{Mg}+\mathrm{Fe})=0.86$. In spite of the apparent cumulus texture, the compositions of magnetite and plenonaste indicate equilibration at sub-solidus temperature, when plotted on the experimentally determined solvus of Turnock \& Eugster (1962). This conclusion would not, however, apply to very wet basaltic magmas at high pressures (around $5 \mathrm{~kb}$ ).

Numerous veins varying from a few centimetres to a few decimetres thick, cut the complex, especially towards its margin. They do not have any obvious preferred orientation. A feature of these veins is the abundance of a fibrous mineral identified by X-ray diffraction as an amphibole (possibly gedrite) along with talc, chlorite and magnesite. Most of these veins show striking zonation and a few show extremely long (up to 15 $\mathrm{cm}$ ) asbestiform fibres orientated subparallel to the vein walls but with their ends kinked round perpendicular to the vein walls (fig. 6). Such a structure probably arose by growth during a period of shear deformation. One vein, about $0.5 \mathrm{~m}$ thick, consists of bladed, pale brown crystals up to $20 \mathrm{~cm}$ in size, which were identified as enstatite with minor talc. Occasionally fragments of a pure talc rock were found in the screes indicating that veins of this mineral may also occur. Finally, veins of chlorite alone were found in a few places with crystals up to pegmatitic size. 
Age

Field relations do not permit an estimate of the age of the Ivnartivaq complex apart from the fact that it is largely conformable with the foliation in the surrounding gneisses - lack of foliation in most of the rocks is no doubt to be attributed to their highly competent nature.

A K-Ar age on separated amphibole gives an early Proterozoic age (1955 $\pm 28 \mathrm{Ma}-\mathrm{P}$. M. Holm, personal communication, 1988).

\section{Conclusions}

The Ivnartivaq complex is a small body (less than 1 $\mathrm{km}^{2}$ ) of serpentinites and dunites approximately concordant with the enclosing gneisses. The contact relationships are ambiguous but a single $\mathrm{K}$-Ar age gives an early Proterozoic age.

The main primary minerals of the complex are olivine, magnetite, spinel, enstatite and clinopyroxene with hornblende and plagioclase in sheets probably rep- resenting original dykes. Later processes have produced extensive marginal areas of serpentinite and a plexus of veins rich in fibrous amphibole, talc, chlorite and magnesite.

The complex apparently arose as a layered igneous intrusion. It is of possible economic interest for its olivine sand (used as a refractory) and the possibility of chromite and precious metal occurrences. However, the olivine sand is unlikely to be present in amounts greater than about 10 million tons (assuming an average thickness of $50 \mathrm{~m}$ ) which would not make it economic. Reconnaissance microprobe analyses have shown that the oxide minerals are relatively poor in $\mathrm{Cr}_{2} \mathrm{O}_{3}$. Asbestiform amphibole may be of interest, and in some cases fibres are long and may be of spinning quality. Talc and related minerals sometimes form clumps suitable for carving and are of interest to local artists for the production of souvenirs for the tourist industry; the occurrence is known locally and has been exploited.

At the present time, no assays are available for precious metals. 